ACTA THERIOLOGICA

Vol. 29, 14: 175-185, 1984

\title{
Comparative Ecology of Sympatric Dipodomys agilis and Dipodomys merriami Populations in Southern California:
}

\author{
Leroy R. McCLENAGHAN
}

\begin{abstract}
McClenaghan L. R., 1983: Comparative ecology of sympatric Dipodomys agilis and Dipodomys merriami populations in southern California. Acta theriol., 29, 14: 175-185 [With 4 Tables \& 1 Fig.].

Sympatric populations of Dipodomys agilis and Dipodomys merriami from San Diego County, California, were monitored by monthly live trapping from September, 1978, through August, 1980. Demographic characteristics of the two species were closely correlated. Both populations displayed relatively stable numbers over the study. Kangaroo rats were most abundant in the winter and spring. Maximum densities for $D$. agilis of 45 per hectare and for $D$. merriami of 29 per hectare were observed. Numbers were lowest as the study concluded in the summer of 1980. Average monthly survival was $86.6 \%$ for $D$. agilis and $85.1 \%$ for $D$. merriami. There were no significant differences in survival between the sexes in either species. The average $D$. agilis remained on the study area for 10.4 months, while the average $D$. merriami remained for 8.3 months. Both species displayed seasonal heterogeneity in reproductive activity, with breeding being most intense in the spring. Periods of recruitment and reproduction were associated with reduced survival in both species.

[Department of Biology, San Diego State University, San Diego, California 92182, U.S.A.].
\end{abstract}

\section{INTRODUCTION}

Desert rodents in North America have been the focus of considerableinvestigation. The primary objective of recent studies has been to identify mechanisms facilitating the coexistence of syntopic species (Brown \& Lieberman, 1973; Price, 1978; Reichman \& Oberstein, 1977; Rosenzweig \& Sterner, 1970; Thompson, 1982a, b). However, there exists a paucity of detailed studies on the dynamics of desert rodent populations (Conley et al., 1977).

The desert-transition zone (Cooper et al., 1976) in eastern San Diego. County, California, is created by the intergradation of chaparral and Colorado Desert communities and contains floral and faunal elements of both these communities. The Pacific kangaroo rat, Dipodomys agilis Gambel, 1848 is a common habitant of chaparral habitats in southern California and northern Baja California, Mexico (Hall \& Kelson, 1959). Dipodomys agilis is at the eastern limit of its distribution in the deserttransition zone. Merriam's kangaroo rat, Dipodomys merriami Mearns, 1890 is a kangaroo rat species whose distribution includes the hottest, driest deserts in North America (Lidicker, 1960). The desert-transition zone represents the western distributional limit for D. merriami (Hall 
\& Kelson, 1959), where it is found in sympatry with D. agilis. This paper reports the results of a two-year study of the dynamics of sympatric $D$. agilis and $D$. merriami populations in southern California.

\section{STUDY AREA}

This study was conducted $6.9 \mathrm{~km} \mathrm{NE}$ of Jacumba California (R. 8E, T. 18S, SW $1 / 4$ of Sec. 1). This site is situated $109 \mathrm{~km} \mathrm{E}$ of San Diego, California, at an elevation of $988 \mathrm{~m}$. Dominant plant species on the study area include juniper (Juniperus californicus), Spanish dagger (Yucca schidigera), Mormon tea (Ephedra californica), jojoba (Simmondsia chinensis), cholla (Opuntia sp.), desert agave (Agave deserti), creosote bush (Larrea tridentata), buckwheat (Eriogonum sp.) and desert apricot (Prunus fremontii).

The climate of this region is typical of Mediterranean-type environments. Winters are moist and cool, while summers are hot and dry. Annual precipitation in this region averages about $330 \mathrm{~mm}$. Most of this precipitation comes in the months of December, January and February.

\section{METHODS}

A $7 \times 7$ trapping grid was established, with an interval of $10 \mathrm{~m}$ between stations $(=0.49 \mathrm{ha})$. Two Sherman livetraps baited with crimped oats were set at each station such that one trap was under the canopy of the nearest shrub greater than $1 \mathrm{~m}$ in height, while the other was in the nearest open area having a diameter of at least $1 \mathrm{~m}$. Trapping was conducted two nights each month from September, 1978 through September, 1980. The grid was run every three hours during the first night and once or twice during the second night of each trapping session. Traps were left open during the day except during the summer, when they were closed to avoid trap deaths of antelope squirrels (Ammospermophilus leucurus).

Upon their initial capture, individuals of both $D$. agilis and $D$. merriami were tagged in the right ear with a uniquely numbered monel fish fingerling tag. Information recorded for each individual captured included the following: location of capture on the grid; microhabitat of capture (open or shrub); weight to the nearest g; position of the testes (abdominal or scrotal) for males; and, for females, the condition of the vagina (perforate or not perforate), nipple size (small, medium or large) and whether or not the individual was obviously pregnant. All individuals were released at the site of their capture.

\section{RESULTS}

\subsection{Trappability}

Monthly population sizes for both Dipodomys agilis and D. merriami were estimated by the direct enumeration of individuals in the trappable population (Krebs, 1966). The accuracy of this technique is dependent upon the trappability of the species being censused (Hilborn et al., 1976). Trappability for both $D$. agilis and $D$. merriami was quantified as the ratio of the number of each species captured in a trapping period to the number known to be alive during the interval. Differential trappability between males and females was tested for by treating the sexes separately. No significant differences in trappability between the sexes in 
any month for either species were observed when these ratios were compared by chi-square tests of independence (Zar, 1974). Seasonal trappabilities were calculated by pooling monthly trappabilities (Table 1). In no season were males and females of either species found to display differential trappability. Seasonal heterogeneity in trappability was tested for by pooling males and females by season and then comparing trappabilities among seasons by chi-square. Both $D$. agilis and D. merriami

Table 1

Trappability of Dipodomys agilis and D. merriari measured as the percent of individuals known to be alive that were actually captured. Seasonal values were obtained by summing over months (Fall $=$ Sept. - Nov.; Winter $=$ Dec. - Feb.; Spring $=$ March - May; Summer $=$ June - Aug.). Numbers in parentheses indicate number known alive in each season. Italics represent values for seasons with statistically significant $(P<0.05)$ differences in trappability within each species.

\begin{tabular}{lcc}
\hline \multirow{2}{*}{ Season } & \multicolumn{2}{c}{ Trappability $(\%)$} \\
\cline { 2 - 3 } & D. agilis & D. merriami \\
\hline Fall 1978 & $81.8(44)$ & $73.9(23)$ \\
Winter 1978-79 & $82.5(57)$ & $87.9(33)$ \\
Spring 1979 & $61.8(55)$ & $41.7(24)$ \\
Summer 1979 & $75.4(65)$ & $86.8(38)$ \\
Fall 1979 & $80.4(51)$ & $79.3(29)$ \\
Winter 1979-80 & $76.6(47)$ & $76.0(25)$ \\
Spring 1980 & $91.1(56)$ & $85.3(34)$ \\
Summer 1980 & $87.2(39)$ & $85.7(14)$ \\
Total & $79.0(414)$ & $78.2(220)$ \\
\hline
\end{tabular}

displayed significant heterogeneity in trappability $\left(\chi^{2}=17.8\right.$ and $\chi^{2}=24.1$, respectively). By subdividing these chi-square tests, it was found that trappabilities for spring 1979 were significantly lower in both Dipodomys species than in other seasons (Table 1). Trappabilities were homogeneous among the remaining seasons for $D$. agilis and D. merriami. Trappability over the entire study was high for both $D$. agilis $(79 \%)$ and $D$. merriami $(78 \%$ ).

\subsection{Changes in Numbers and Sex Ratios}

Monthly values for the minimum numbers of $D$. agilis and $D$. merriami known to be alive are given in Figure 1. Numbers for both species were strikingly stable over most of the study. Slight peaks in numbers of both species occurred during winter 1978-79, summer 1979 and spring 1980. Lowest numbers for both $D$. agilis and D. merriami were observed as the study was concluded at the end of summer 1980. Patterns of change in the two species closely paralleled one another. In any given month, the number of $D$. agilis known to be alive on the study site Acta theriol. 3 
$(\bar{x}=17.25)$ was approximately twice that observed for $D$. merriami $(\bar{x}=9.17)$. Monthly numbers of males and females known to be alive were compared for each species by chi-square tests. No significant departures from a 1:1 ratio were observed for either species in any month.

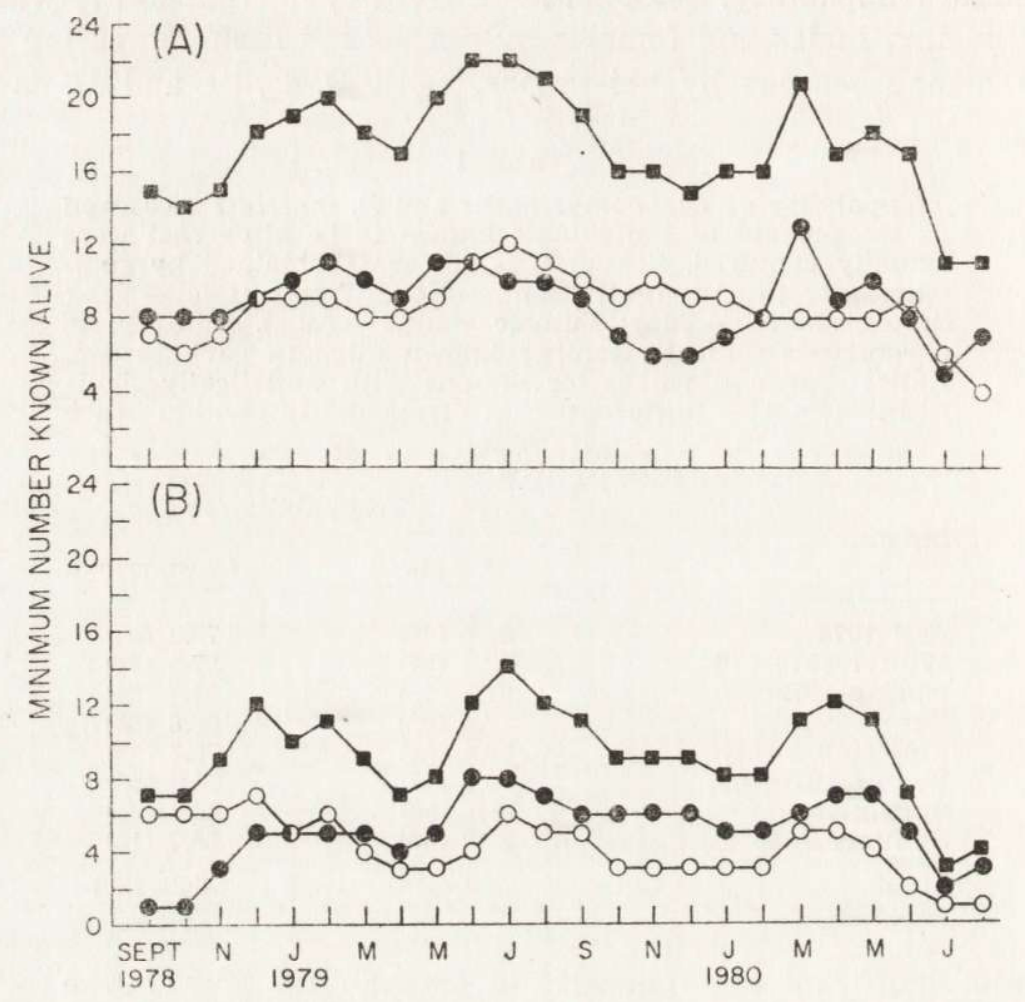

Fig. 1. Minimum numbers of Dipodomys agilis (A) and D. merriami (B) known to be alive from September, 1978, through August, 1980. Solid squares represent total numbers, while solid and open circles represent numbers of males and females, respectively.

\subsection{Survival and Longevity}

Survival was measured as the minimum survival rate for animals known to be alive in each month summed by season. The sexes were first considered separately. Chi-square tests indicated that survival was independent of sex in all seasons for both species. Minimum survival rates by season with sexes pooled are given in Table 2. For D. agilis, survival was high in the fall and winter and somewhat lower in the spring and summer. Spring and summer of 1980 were seasons of lowest survival. The average monthly survival rate for $D$. agilis over the course of the study was $86.6 \%$. Patterns of survival were less clear in the D. merriami population, although lowest survival was again observed in the spring and summer of 1980 . Survival in the D. merriami population 
was generally high in the fall, but winter and spring displayed striking differences between years. Average monthly survival for $D$. merriami was $85.1 \%$.

Estimates of average length of life on the study area for each species were calculated as the average number of months that individuals tagged during the first year of the study and recaptured at least once remained on the study area. The mean lengths of life $\pm 1 \mathrm{SE}$ for $D$. agilis and D. merriami were $10.4 \pm 1.2$ and $8.3 \pm 1.3$ months, respectively. These means were not significantly different $(t=1.26, P>0.2)$.

\subsection{Recruitment}

For both $D$. agilis and D. merriami, recruitment was assessed by summing for each season the monthly proportion of newly tagged individuals in the trappable population (Table 3). No significant hetero-

Table 2

Percent minimum monthly survival for Dipodomys agilis and $D$. merriami. Rates for males and females were homogeneous within seasons and have been pooled. Seasonal rates were obtained by summing monthly rates seasons. Sample sizes appear in parentheses.

\begin{tabular}{|c|c|c|}
\hline \multirow{2}{*}{ Season } & \multicolumn{2}{|c|}{ Minimum Monthly Survival ( $\%$} \\
\hline & D. agilis & D. merriami \\
\hline Fall 1978 & $95.4(44)$ & $100.0(23)$ \\
\hline Winter $1978-79$ & $96.5(57)$ & 75.8 \\
\hline Spring 1979 & $89.1(55)$ & $91.7(24)$ \\
\hline Summer 1979 & $8 ? .1(65)$ & $89.5(38)$ \\
\hline Fall 1979 & $90.2(51)$ & 89.7 (29) \\
\hline Winter $1979-80$ & 97.9 (47) & $96.0(25)$ \\
\hline Spring 1980 & $76.8(56)$ & 70.6 (34) \\
\hline Summer 1980 & $64.1(39)$ & $57.1(14)$ \\
\hline Average $\pm 1 \mathrm{SE}$ & $86.6 \pm 2.5(414)$ & $85.1 \pm 3.6(220)$ \\
\hline
\end{tabular}

geneity in recruitment within seasons between years was observed for either species. Average monthly recruitment over the entire study was $11.3 \%$ for $D$. agilis and $14.5 \%$ for $D$. merriami. Recruitment rates were heterogeneous among seasons in $D$. agilis $\left(\chi^{2}=14.8, P<0.001\right)$, with recruitment in the summer being greater than that for other seasons (Takle 3). While spring and summer appeared to be seasons of greatest recruitment in $D$. merriami no significant heterogeneity among seasons vas observed $\left(\chi^{2}=5.1, P>0.1\right)$.

\subsection{Reproduction}

Patterns of reproductive activity were explored by calculating the proportion of breeding adults in each population. Adults were identified on the basis of body weight ( $>57 \mathrm{~g}$ for $D$. agilis and $>36 \mathrm{~g}$ for D. merria- 
$m i)$. Males with scrotal testes and females with perforate vaginas and/or medium or large nipples were judged to be reproductive. Seasonal reproductive parameters were obtained by summing over months (Table 3 ). Chi-square analysis was used to test for heterogeneity in breeding activity between sexes within seasons, within seasons between years for each sex and among seasons for each sex.

Differential breeding activity between the sexes in $D$. agilis was observed in winter 1978-79 $\left(\chi^{2} 14.2, \quad P<0.001\right)$, fall $1979\left(\chi^{2}=5.9\right.$, $P<0.05)$ and winter $1979-80\left(\chi^{2}=5.9, P<0.05\right)$. A larger proportion of males than females were reproductive in these seasons (Table 3). For male $D$. agilis, no significant heterogeneity in breeding activity was observed for any season between years. However, there was considerable heterogenity among seasons $\left(\chi^{2}=34.9, P<0.001\right)$. By subdividing this chi-square, the seasons may be arranged with respect to breeding activity as follows: spring $>$ winter, summer $>$ fall. Female $D$. agilis

\section{Table 3}

Recruitment rates and percentages of adults in reproductive condition for Dipodomys agilis and $D$. merriami. Seasonal parameters were obtained by summing monthly values. Recruits were defined as any newly tagged individuals. Adults were identified on the basis of body weight $(>57 \mathrm{~g}$ for D. agilis and $>36 \mathrm{~g}$ for D.merria$m i)$ Males with scrotal testes and females with perforate vaginas and/or medium or large nipples were judged to be reproductive. Samples sizes appear in parentheses. $\mathrm{F}$ - fall, W - winter, Sp - spring, Su - summer.

\begin{tabular}{|c|c|c|c|c|c|c|}
\hline \multirow{3}{*}{ Season } & \multicolumn{2}{|c|}{ Recruitment Rate (\%) } & \multicolumn{4}{|c|}{ Reproductive Activity (\%) } \\
\hline & \multirow{2}{*}{ D. agilis } & \multirow{2}{*}{ D. merriami } & \multicolumn{2}{|c|}{ D. agilis } & \multicolumn{2}{|c|}{ D. merriami } \\
\hline & & & $0^{7} 0^{7}$ & 우우 & $\sigma^{x} \sigma^{x}$ & qq \\
\hline F. 1978 & $6.9(29)$ & $12.5(16)$ & 33.3 (18) & $22.2(9)$ & 75.0 & $33.3(12)$ \\
\hline W. $1978-79$ & $10.5(57)$ & $21.2(33)$ & $76.0(25)$ & 11.8 & 50.0 & $9.1(11)$ \\
\hline Sp. 1979 & $7.3(55)$ & $8.3(24)$ & 88.9 (18) & 71.4 (14) & 100.0 & 100.0 \\
\hline Su. 1979 & $20.0(65)$ & 21.1 (38) & 56.2 (16) & 58.8 (17) & 66.7 (18) & 36.4 (11) \\
\hline F. 1979 & $3.9(51)$ & $3.4(29)$ & 47.1 (17) & $5.6(18)$ & $6.0(16)$ & 9.1 (11) \\
\hline W. $1979-80$ & $4.3(47)$ & 0.0 (25) & 93.8 (16) & $46.2(13)$ & $70.0(10)$ & $44.4(9)$ \\
\hline Sp. 1980 & $16.1(56)$ & $26.5(34)$ & 100.0 (29) & $90.5(21)$ & 100.0 (17) & 100.0 (11) \\
\hline Su. 1980 & $23.1(39)$ & $21.4(14)$ & $84.6(13)$ & 81.8 (11) & $66.7(9)$ & $50.0(2)$ \\
\hline Av. $\pm 1 \mathrm{SE}$ & $\begin{array}{c}11.3 \pm 1.9 \\
(399)\end{array}$ & $\begin{array}{c}14.5 \pm 2.6 \\
(213)\end{array}$ & $\begin{array}{c}73.7 \pm 5.9 \\
(135)\end{array}$ & $\begin{array}{c}51.6 \pm 7.5 \\
(120)\end{array}$ & $\begin{array}{c}61.6 \pm 7.7 \\
(95)\end{array}$ & $\begin{array}{c}44.0 \pm 8.7 \\
(70)\end{array}$ \\
\hline
\end{tabular}

similarly showed no difference in the intensity of reproductive activity for any season between years, but significant heterogenity among seasons was observed $\left(\chi^{2}=36.8, P<0.001\right)$. Breeding activity for adult females was greatest in spring and summer and lowest in the fall and winter.

When proportions of breeding $D$. merriami males and females were compared within seasons, no significant differences were found (Table 3). Females displayed no differences in breeding activity for any season between years. Males also displayed no heterogeneity within seasons between years except for fall, where the proportion of breeding males in fall 1978 was significantly greater than that in fall $1979\left(\chi^{2}=8.8\right.$, 
$P<0.001)$. Significant heterogeneity in breeding activity among seasons was observed in both males $\left(\chi^{2}=41.5, P<0.001\right)$ and females $\left(\chi^{2}=25.7\right.$, $P<0.01$ ). Intensity of reproductive activity for males can be ordered as follows: spring $>$ winter, summer, fall 1978>fall 1979; for females: spring $>$ winter, summer, fall.

\subsection{Correlations of Demographic Parameters}

Demographic parameters were averaged by season for each species. Correlation analysis was used to measure the correlation of demographic parameters within and between kangaroo rat populations (Table 4). Se-

Table 4

Correlations $(\mathrm{df}=6)$ among seasonal demographic parameters for populations of Dipodomys agilis (above diagonal) and D. merriami (below diagonal). Interspecific comparisons are given on the diagonal. Comparisons are not statistically significant $(P>0.05)$ unless otherwise indicated.

\begin{tabular}{lccccc}
\hline & $\begin{array}{c}\text { Min. no. } \\
\text { alive }\end{array}$ & $\begin{array}{c}\text { Survival } \\
\text { rate }\end{array}$ & Recruitment & $\begin{array}{c}\text { Male } \\
\text { repro. }\end{array}$ & $\begin{array}{c}\text { Female } \\
\text { repro. }\end{array}$ \\
\hline Min. no. alive & $0.92^{* *}$ & 0.20 & 0.21 & 0.02 & 0.01 \\
Survival rate & 0.22 & $0.81^{*}$ & $-0.85^{* *}$ & -0.31 & $-0.73^{*}$ \\
Recruitment & 0.27 & -0.69 & $0.82^{*}$ & 0.22 & 0.65 \\
Male repro. & -0.09 & -0.08 & 0.35 & 0.53 & 0.67 \\
Female repro. & -0.11 & -0.17 & 0.21 & $0.83^{* *}$ & $0.84^{* *}$ \\
\hline
\end{tabular}

${ }^{*} P<0.05,{ }^{* *} P<0.01$

veral patterns emerge from the comparison of parameters within each species. First, changes in the numbers of each species were not significantly correlated with any of the other demographic variables in either Dipodomys agilis or D. merriami (Table 4). This probably reflects the relative stability in numbers displayed by both populations (Fig. 1). Second, there was a trend in both species for survival rates to be negatively associated with recruitment and reproductive activity. Correlations of survival rate with recruitment $(r=-0.85)$ and with percent females breeding $(r=-0.73)$ were significant in $D$. agilis. In $D$. merriami, the correlation between survival rate and recruitment $(r=-0.69)$ was not quite significant. When seasonal demographic parameters were compared for the two kangaroo rat populations, correlations of the same parameter between populations (e.g. D. agilis survival vs. D. merriami survival) were significant and positive in four of the five possible comparisons; only male reproductive activity was not significantly correlated between the two populations.

\section{DISCUSSION}

Both Dipodomys agilis and D. merriami populations displayed similar patterns of change in numbers (Fig. 1). Kangaroo rats were most abun- 
dant in late winter and spring and least abundant in the summer and fall. Previous studies have reported summer peaks in numbers for D. merriami (Reynolds, 1958; Chew \& Chew, 1970) and winter peaks for D. agilis (MacMillen, 1964). In July, 1979, 36 kangaroo rats (22 D. agilis and $14 \mathrm{D}$. merriami) were known to be alive on the study site. Given that the trapping grid covered $3600 \mathrm{~m}^{2}$ and allowing for a $10 \mathrm{~m}$ boundry strip, these numbers are equivalent to densities of 45 animals per hectare and 29 animals per hectare for $D$. agilis and D. merriami, respectively. While the area actually sampled by the grid may be somewhat greater than 0.49 hectares, these density estimates are noteworthy because they far exceed those reported for these species in other studies. Conley e.t al. (1977), in summarizing demographic characteristics for a variety of Chihuahuan Desert rodent species, cited a maximum density of 18.29 individuals per hectare for $D$. merriami from a study by Reynolds (1950). Christopher (1973) calculated a density of 18.5 animals per hectare for a population of $D$. merriami on the western edge of the Colorado Desert. Reported densities (individuals per hectare) for D. agilis include 10.8 (Christopher, 1973), 11.9 (MacMillen, 1964) and 13.0 (M'Closkey, 1972).

Both $D$. agilis and $D$. merriami displayed relatively high survival during the study. No differences in survival rates were observed between the sexes in either kangaroo rat population. M'Closkey (1972) also observed similar survival in $D$. agilis for males and females. Spring and summer were typically seasons of lower survival (Table 2). The association of reduced survival with high densities and reproductive activity is consistent with the results of studies on other desert rodents (Christian, 1980; Conley et al., 1977; French et al., 1966). Periods of good survival were typically those of low recruitment (fall, winter), while seasons with lower survival were characterized by higher recruitment rates (spring, summer). Average life spans for D. agilis and D. merriami, 10.4 and 8.3 months, respectively, were longer than those previously reported for these species. M'Closkey (1972) observed an average length of life of 4.4 months for D. agilis, while French et al. (1967) reported life spans of only 4.7 and 1.7 months for fenced and unfenced populations of D. merriami in Nevada.

In $D$. agilis, reproductive individuals of both sexes were present in all seasons, while reproductive males and females in the D. merriami population were present in all seasons except fall 1979 (no males). Generally, a greater proportion of males than females was reproductive in any given season. Bradley \& Mauer (1971) reported the presence of reproductive males in all months of the year for $D$. merriami in Nevada, with spring peaks in breeding activity. MacMillen (1964) observed lactating $D$. agilis from January through July and reproductive males from December through July. In the present study, both D. agilis and 
D. merriami displayed peaks in reproductive activity during the spring (Table 3). This result agrees with other studies in which an association between reproduction in desert rodents and the availability of green vegetation has been observed (Beatley, 1969, 1976; Bradley \& Mauer, 1971; Christian, 1980; Reynolds, 1958). Demands for energy and water are increased by lactation in small mammals (Randolph et al., 1977; Soholt, 1978) and green vegetation in the desert-transition zone is most abundant in the spring following the winter rains.

Nichols et al. (1976) have proposed a life history model for desert rodents in which species employ temporal shifts between a relative $r$-strategy and a relative $K$-strategy (MacArthur \& Wilson, 1967) in response to environmental fluctuations. Periods of precipitation and increased plant productivity are exploited by desert rodents through increased reproduction. However, this exploitation confers a "cost" to the rodents in the form of reduced survival as individuals forage, search for mates and related activities. Exposure to mortality factors and reproductive rates are reduced during periods of environmental adversity as individuals spend more time inactive in their burrows. This model predicts high survivorship and low reproduction during adverse environmental conditions and negative associations of survivorship with reproduction and recruitment. Demographic patterns observed in this study of $D$. agilis and D. merriami conform to these predictions (Table 4).

Acknowledgements: This work was supported by a grant-in-aid from the San Diego State University Foundation. Help in the field was provided by J. Anderson, A. Beauchamp, T. Peterson, T. Spevak and W. Randall.

\section{REFERENCES}

1. Beatley J. C., 1969: Dependence of desert rodents on winter annuals and precipitation. Ecology, 50: 721-724.

2. Beatley J. C., 1976: Rainfall and fluctuating plant populations in relation to distribution and numbers of desert rodents in southern Nevada. Oecologia, 24: $21-42$.

3. Bradley W. G. \& Mauer R. A., 1971: Reproduction and food habits of Merriams's kangaroo rat, Dipodomys merriami. J. Mammal., 52: 497-507.

4. Brown J. H. \& Lieberman G. A., 1973: Resource utilization and coexistence of seed-eating desert rodents in sand dune habitats. Ecology, 54: 788-797.

5. Chew R. M. \& Chew A. E., 1970: Energy relationships of the mammals of a desert shrub (Larrea tridentata) community. Ecol. Monogr., 40: 1-21.

6. Christian D. P., 1980: Patterns of recovery from low numbers in Namib Desert rodents. Acta theriol., 25: 431-450.

7. Christopher E. A., 1973: Sympatric relationships of the kangaroo rats, Dipodomys merriami and Dipodomys agilis. J. Mammal., 54: 317-326.

8. Conley W., Nichols J. D. \& Tipton A. R., 1977: Reproductive strategies in desert rodents. [In: "Transactions of the symposium on the biological resources of the Chihuahuan Desert region, United States and Mexico", R. H. Wauer, D. H. Riskind, eds.]. U.S. Nat. Park Service No. 3: 193-215. 
9. Cooper C. F., Zedler P. H., Winfield T., Rieger J. P. \& Mahrdt C. R., 1976: Ecological resources and sensitivities of extreme southern California. Center Reg. Envi. Stud., San Diego State Univ. 120 pp.

10. French N. R., Maza B. G. \& Aschwanden A. P., 1966; Periodicity of desert rodent activity. Science, 154: 1194-1195.

11. French N. R., Maza B. G. \& Aschwanden A. P., 1967: Life spans of Dipodomys and Perognathus in the desert. J. Mammal., 48: 537-548.

12. French N. R., Maza B. G., Hill H. O., Aschwanden A. P. \& Kaaz H. W., 1974: A population study of irradiated desert rodents. Ecol. Monogr., 44: 45-72.

13. Hall E. R. \& Kelson K. R., 1959: The Mammals of North America. Vol. 1. Ronald Press: 1-542. New York.

14. Hilborn R., Redfield J. A., \& Krebs C. J., 1976: On the reliability of enumeration for mark and recapture census of voles. Can. J. Zool., 54: 1019-1024.

15. Krebs C. J., 1966: Demographic changes in fluctuating populations of Microtus californicus. Ecol. Monogr., 36: 239-273.

16. Lidicker W. Z., Jr., 1960: An analysis of intraspecific variation in the kangaroo rat Dipodomys merriami. Univ. Calif. Publ. Zool., 67: 125-218.

17. M'Closkey R. T., 1972: Temporal changes in populations and species diversity in a California rodent community. J. Mammal., 53: 657-676.

18. MacArthur R. H. \& Wilson E. O., 1967: The Theory of Island Biogeography. Princeton Univ. Press.

19. MacMillen R. E., 1964: Population ecology, water relations, and social behavior of a southern California semidesert rodent fauna. Univ. Calif. Publ. Zool., 71: $1-66$.

20. Nichols J. D., Conley W., Batt B. \& Tipton A. R., 1976: Temporally dynamic reproductive strategies and the concept of $r$ - and $K$-selection. Amer. Natur., 110: $995-1005$.

21. Price M. V., 1978: The role of microhabitat in structuring desert rodent communities. Ecology, 59: 910-921.

22. Randolph P. A., Randolph J. C., Mattingly K. \& Foster M. M., 1977: Energy costs of reproduction in the cotton rat, Sigmodon hispidus. Ecology, 58: 31-45.

23. Reichman O. J. \& Oberstein D., 1977: Selection of seed distribution types by Dipodomys merriami and Perognathus amplus. Ecology, 58: 636-643.

24. Reynolds H. G., 1950: Relation of Merriam kangaroo rats to range vegetation in southern Arizona. Ecology, 31: 456-463.

25. Reynolds H. G., 1958: The ecology of the Merriam kangaroo rat (Dipodomys merriami) on the grazing lands of southern Arizona. Ecol. Monogr., 28: 111-127.

26. Rosenzweig M. L. \& Sterner P. W., 1970: Population ecology of desert rodent communities: body size and seed-husking as bases for heteromyid coexistence Ecology, 51: 217-224.

27. Soholt L. F., 1978: Consumption of herbaceous vegetation and water during reproduction and development of Merriam's kangaroo rat, Dipodomys merriami, Amer. Midl. Natur., 98: 445-457.

28. Thompson S. D., 1982a: Microhabitat utilization and foraging behavior of bipedal and quadrupedal heteromyid rodents. Ecology, 63: 1303-1312.

29. Thompson S. D., 1982b: Structure and species composition of desert heteromyid rodent species assemblages: effects of a simple habitat manipulation. Ecology, 63: $1313-1321$.

30. Zar J. H., 1974: Biostatistical analysis. Prentice-Hall, Englewood Cliffs, New Jersey.

Accepted, February 17, 1984. 
Leroy R. McCLENAGHAN

\section{POROWNAWCZA EKOLOGIA SYMPATRYCZNYCH POPULACJI DIPODOMYS AGILIS I DIPODOMYS MERRIAMI W POEUDNIOWEJ KALIFORNII}

\section{Streszczenie}

Badania nad sympatrycznymi populacjami Dipodomys agilis i D. merriami prowadzono w okolicach San Diego od września 1978 do sierpnia 1980 r. włącznie, przy pomocy comiesięcznych odłowów w pułapki żywołowne (Tabela 1). Charakterystyka demograficzna tych dwóch gatunków była bardzo podobna (Tabela 4). W ciągu okresu badań obie populacje miały względnie stałą liczebność. D. agilis były liczniejsze w zimie i na wiosnę. Maksymalne zagęszczenie tego gatunku wynosiło 45 osobników/ha, a D. merriami - 29/ha. Najniższą liczebność zanotowano w lecie 1980 r. (Ryc. 1). Srednia miesięczna przeżywalność wynosiła 86,6\% dla D. agilis i $85.1 \%$ dla $D$. merriami (Tabela 2). Nie wystąpiły istotne różnice w przeżywalności samców i samic obu gatunków. D. agilis pozostaje średnio przez 10.4 miesiąca na badanym areale, podczas gdy $D$. merriami tylko 8.3 miesiąca. Oba gatunki wykazują sezonową zmienność aktywności rozrodczej, przy czym najintensywniejszy rozród jest na wiosnę. Okres rozrodu i wychodzenia młodych z gniazd cechował się obniżoną przeżywalnością osobników obu gatunków (Tabela 3). 